\title{
REVIEW OF RESEARCH ON ALCOHOL DEPENDENCE IN A MODEL OF MICE SELECTED FOR HIGH AND LOW STRESS-INDUCED ANALGESIA
}

\section{PRZEGLĄD BADAŃ NAD UZALEŻNIENIEM OD ALKOHOLU W MODELU MYSZY SELEKCJONOWANYCH W KIERUNKU WYSOKIEJ I NISKIEJ ANALGEZJI POSTRESOWEJ}

\author{
Piotr Poznański ${ }^{1(\mathrm{~A}, \mathrm{~B}, \mathrm{C}, \mathrm{D}, \mathrm{E}, \mathrm{F})}$, Anna Leśniak ${ }^{2(\mathrm{~A}, \mathrm{~B}, \mathrm{C}, \mathrm{D}, \mathrm{E}, \mathrm{F})}$, Joanna Strzemecka $^{3(\mathrm{E}, \mathrm{F})}$, \\ Mariusz Sacharczuk ${ }^{1,2(A, B, C, D, E, F, G)}$
}

${ }^{1}$ Laboratory of Neurogenomics, Institute of Genetics and Animal Breeding, Polish Academy of Sciences, Jastrzebiec, Poland

${ }^{2}$ Department of Pharmacodynamics, Centre for Preclinical Research and Technology and Department of Internal Medicine, Hypertension and Vascular Diseases, Medical University of Warsaw, Poland ${ }^{3}$ Institute of Health Sciences, Pope John Paul II State School of Higher Education, Biała Podlaska, Poland

Authors' contribution Wkład autorów:

A. Study design/planning zaplanowanie badań

B. Data collection/entry zebranie danych

C. Data analysis/statistics dane - analiza i statystyki D. Data interpretation interpretacja danych E. Preparation of manuscript przygotowanie artykułu F. Literature analysis/search wyszukiwanie i analiza literatury G. Funds collection zebranie funduszy
Tables: 0

Figures: 0

References: 41

Submitted: 2018 May 29

Accepted: 2018 Jun 19

\section{Summary}

Decades of studies on alcohol dependence showed that it is a very complex and multifactorial disorder. Several receptor systems are involved in development and susceptibility to alcohol abuse; however, there are some which play a crucial role in its pathogenesis, e.g. dopaminergic or opioid system. In this paper, an effort is made to explain the role of endogenous opioid system activity in alcohol dependence. To achieve the goal, we use a unique model is used which shows mice lines that are divergently selected for high (HA) and low (LA) stress-induced analgesia. This process allowed for selecting individuals characterised by hyperactive (HA) or hypoactive (LA) opioid system. Basing on the performed experiments, we proved that delta opioid receptors play a critical role in the development of addiction. The most notable achievement is an unspecific reaction of mice with the hyperactive opioid system to naloxone - an unspecific opioid system antagonist, which is currently approved in the pharmacotherapy of dependent patients.

Keywords: alcohol abuse, selected mouse lines, opioid system

\section{Streszczenie}

Uzależnienie od alkoholu jest chorobą wieloczynnikową, za której etiologię odpowiedzialnych jest kilka mechanizmów. Wieloletnie badania pozwoliły na zidentyfikowanie kilku układów receptorowych, które sa zaangażowane w rozwój oraz podatność do uzależnienia od alkoholu, jednakże niektóre z nich odgrywają krytyczną rolę w jego patogenezie np. układ dopaminergiczny lub opioidowy. W niniejszym artykule przedstawiamy wyniki badań, których celem było określenie roli endogennej aktywności układu opioidowego w uzależnieniu od alkoholu. Do realizacji tego celu wykorzystano unikalny model myszy selekcjonowanych w kierunku wysokiej (HA) oraz niskiej (LA) analgezji postresowej. Proces selekcji pozwolił na wybranie osobników charakteryzujących się wysoką (HA) oraz niską (LA) aktywnością układu opioidowego. Na podstawie przeprowadzonych eksperymentów, udowodniliśmy krytyczną rolę receptorów opioidowych typu delta w rozwoju uzależnienia od alkoholu. Godnym uwagi osiągnięciem było wykazanie niespecyficznej reakcji myszy o wysokiej aktywności układu opioidowego na nalokson - niespecyficznego antagonistę receptorów opioidowych, który jest aktualnie używany w farmakoterapii uzależnionych pacjentów.

Słowa kluczowe: uzależnienie od alkoholu, selekcjonowane linie myszy, układ opioidowy

\section{Introduction}

Alcohol dependence is a multi-stage relapsing disorder, whose etiology is not fully understood. It is believed that several mechanisms are engaged in the development and course of alcohol illness. The complexity of this disorder manifests itself by the involvement of several receptor systems (glutaminergic, GABAergic, opioid, cannabinoid, dopaminergic, cholinergic, serotonergic) in mediating the rewarding and reinforcing effects of ethanol $[1,2,3]$. The abovementioned stages of which alcohol abuse consists of are: I - initiation of ethanol

Poznański P, Leśniak A, Strzemecka J, Sacharczuk M. Review of research on alcohol dependence in a model of mice selected for high and low stress-induced analgesia. Health Prob Civil. 2018; 12(3): 217-222. https://doi.org/10.5114/hpc.2018.76747

Address for correspondence / Adres korespondencyjny: Mariusz Sacharczuk, Laboratory of Neurogenomics, Institute of Genetics and Animal Breeding, Polish Academy of Sciences, Postępu 36A, 05-552 Jastrzebiec, Poland, e-mail: msacharczuk@wum.edu.pl, phone +48 227367000

Copyright: (C) Pope John Paul II State School of Higher Education in Biała Podlaska, Piotr Poznański, Anna Leśniak, Joanna Strzemecka, Mariusz Sacharczuk. This is an Open Access journal, all articles are distributed under the terms of the Creative Commons Attribution-NonCommercial-ShareAlike 4.0 International (CC BY-NCSA 4.0) License (http://creativecommons.org/licenses/by-nc-sa/4.0/), allowing third parties to copy and redistribute the material in any medium or format and to remix, transform, and build upon the material, provided the original work is properly cited and states its license. 
consumption, II - maintenance of consumption, III - craving and IV - relapse. It is environmental factors (i.e. stress) that are mainly responsible for the first phase of alcohol dependence. The further stage is caused by genetic factors (i.e. polymorphisms in alcohol metabolism genes) or genetic-environmental factors interactions. Craving or reinstatement of reward results from neuroadaptations, mainly in glutaminergic and GABAergic transmission, occurring during chronic ethanol ingestion $[4,5,6]$. As there is no effective pharmacotherapy of dependent patients, most of them return to alcohol drinking within three-years after the therapy [7].

The impact of the opioid system neurotransmission on the development and course of alcohol dependence is well-documented, hence experiments in which mouse characterised by high and low endogenous opioid system activity are used may help in better understanding of its role in the addiction process or trying to develop some new pharmacotherapies [3,8]. This model is well documented in the subjects with alcohol dependence $[9,10,11]$, effects of chronic mild stress (CMS) [12], melanoma growth [13,14], and morphine efficacy [15]. It was developed on the basis of differences in the level of stress-induced analgesia (SSIA) resulting from the opioid system activity [16]. Thence two contrary lines were established: high-analgesia (HA), characterised by very high phenomenon of SSIA and low-analgesia (LA). Despite different endogenous opioid system activity, both lines have distinct blood-brain barrier (BBB) permeability [17]. Opposing to LA mice, HA mice have a very low selectivity of the $\mathrm{BBB}$, which is the effect of lower expression of cell adhesion proteins - claudins and occludins [18].

To this date, over 90 generations of HA and LA were bred and selection is still maintained according to the protocol outlined in the Institute of Genetic of Animal Breeding of Polish Academy of Sciences [16,19]. In this paper, current findings on alcohol dependence in this unique model are presented. Secondly, the issue of morphine tolerance is discussed.

\section{Aim of the work}

The goal of this paper is to show current findings on alcohol dependence in this unique model of mice.

\section{Alcohol dependence in HA and LA mice}

As it was mentioned above after many years of research, it is well-documented that opioid system plays a critical role in the development of ethanol dependence and further ethanol consumption [3,20]. Activation of specific types of opioid receptors, after alcohol administration, may result in producing rewarding (delta and mu opioid receptors activation) or aversive (kappa opioid receptors activation) effects [21,22]. Due to high differences in endogenous opioid system activity, HA and LA mice were proposed as a good model to study the effect of this receptor system in ethanol dependence [9]. However, these lines cannot be considered as alcohol preferring and non-preferring lines, because of aversion to 8\% alcohol and low difference of ethanol preference between them; approximately 25\% preference in LA and 10\% in HA mice in normal conditions [9]. Additionally, metabolism of alcohol is on the same level in both lines, which was assessed by measuring blood ethanol concentration (BEC) [10].

The first study performed on HA and LA lines on ethanol dependence proved that the congenital difference in endogenous opioid system activity causes differences in ethanol intake. In normal conditions, hyperactivity of this receptor system slightly decreases the daily consumed amount of ethanol [9]. Applying chronic mild stress (CMS) conditions causes that the LA mice are more likely to drink ethanol - almost 5 times more than in normal conditions, while there was no change of preference in the HA strain. Therefore, it has been postulated that CMS reveals a hidden phenotype, where a low endogenous activity of the opioid system plays a critical role in the predisposition to the development of alcohol dependence [9]. Further studies showed that a chronic stress stimulus leads to the development of depressive-like behaviour only in the mice characterised by a high endogenous activity of the opioid system, which was assessed in a tail-suspension test (TST). Moreover, the hotplate test (HP) revealed that stressful conditions are responsible for a slight increase of nociception in the HA mice, whereas there was no such effect in the LA mice. Ingestion of small doses of ethanol by the high analgesia mice caused an attenuation of CMS-induced depressive-like behaviour and pain perception [12].

Sequencing the Oprd1 gene, which codes delta opioid receptors, revealed an interesting transition C320T resulting in an A107V substitution, present in the colony of HA and LA mice [10]. In both lines, individuals with the CT genotype demonstrate an increased ethanol intake and preference, both in normal and CMS conditions, but the genotype effect is more significant in the mice with the endogenously hypoactive opioid system. Similarly to the previous studies, the development of depressive-like behaviour was defined by TST. After ingestion of ethanol under normal conditions, immobility time during TST remained unchanged in both genotypes of HA and LA mice. However, under stressful conditions, the presence of C320T transition results in a lower anti- 
depressive effect of ethanol in the HA mice. Surprisingly, in the CT LA mice, ethanol caused pro-depressive effect despite a small effect of CMS [10].

The latest study performed on these divergently selected mouse lines focused on determining the role of endogenous opioid system activity and the subtypes of opioid receptors in the development of alcohol dependence [11]. Non-selective pharmacological antagonism of the opioid system by intraperitoneal administration of naloxone (NLX) resulted in a drastic increase of ethanol intake and preference in mice with a hyperactive opioid system. The development of depressive-like and anxiety-like behaviour, assessed in the TST and elevated-plus maze test (EPM), was observed during NLX therapy in HA mice, which may be a possible mechanism responsible for their high increase of ethanol consumption parameters. Ethanol ingestion had an anti-depressive and anxiolytic effect making individuals feel better and leading to uncontrolled ethanol consumption. This result is very interesting, as it points to a danger of using other non-selective antagonist of the opioid system - naltrexone, which is FDA approved drug in the therapy of alcohol-dependent patients [11]. However, stimulation of this receptor system by morphine caused slight attenuation of ethanol self-administration in both lines, but in the HA mice, the effect was more pronounced [Unpublished data].

An administration of a selective DOR antagonist - naltrindole (NTI), resulted in a very high increase of ethanol intake and preference - almost 90\% preference for ethanol in HA mice, while no effect of DOR blockade was observed in LA mice. Results from other studies on DOR impact on ethanol consumption are not consistent. Some studies point out that the blockage of DOR or knock out of DOR gene induces ethanol intake [23,24,25]. However, there are also many studies reporting that treatment by DOR specific antagonists causes attenuation of ethanol drinking parameters $[26,27,28,29]$. Differences may result from different animal models used in the experiments but also because of the presence of delta and delta $_{2}$, which have an opposing effect on ethanol consumption [30]. Moreover, the administration of NTI to CT heterozygotes of both lines caused no effect, despite their higher basal ethanol preference. It has been proven that C320T transition causes dysfunction of the DOR, resulting in the absence of NTI effect on ethanol consumption $[10,11]$. While comparing the studies by Sacharczuk et al. and Poznanski et al., different degree in response to congenital dysfunction and pharmacological blockage between HA and LA mice is explained by the possibility of compensation of delta opioid receptors dysfunction by mu opioid receptors in HA individuals with C320T transition, hence the genetic effect is more significant in LA mice. Additionally, pharmacological antagonism is 'artificial' at a specific point in time, thus there is no compensation mechanism established, and effect of the pharmacological blockade is more significant in HA mice [10,11].

Using cyprodime (CYP) - a selective MOR antagonist, induced an effect in the same manner as DOR blockage but with lower efficiency. This result is not consistent with other studies considering MOR blockage or MOR KO mice $[31,32,33]$. It has been proposed that difference may be a result of the development of the compensatory mechanism, which may neutralise the lack of rewarding the effect of endogenous opioids [11].

The antagonism of third opioid receptor subtype - KOR, by nor-Binaltorphinine slightly brought down ethanol intake and preference [11]. A number of pharmacological and knock-out studies indicate that impairment of dynorphin/kappa opioid receptor system causes attenuation of voluntary ethanol consumption $[34,35,36,37,38]$. Morales et al. observed that nor-Binaltorphimine attenuated a voluntary ethanol intake in female adults. They concluded that it might be related to sex differences in response to stressful situations (e.g. isolate-housing) [38]. Another publication reported that a systemic administration of nor-Binaltorphimine causes attenuation of ethanol consumption only in ethanol-dependent animals, while there was no effect in nondependent individuals [36]. Also, mice lacking kappa opioid receptors or preprodynorphin displayed a lower ethanol intake than their wild-type counterparts [34,35].

To this date, studies on alcohol dependence performed on HA and LA mice confirmed that the opioid system plays an essential role in the risk of occurrence and course of alcohol dependence. They also showed that the role of the interaction between genetic risk factors (low endogenous opioid system activity) and environmental factors (chronic mild stress) is critical in the development of ethanol dependence $[9,10,11,12,39]$. Also, it has been proven that DOR plays a major role in the development and course of alcohol illness [10,11]. The results obtained from these dependence studies may also lead to the explanation of the low therapeutic effect of nonselective antagonists of the opioid system in the pharmacotherapy of addicts. Ineffectiveness of this drug has been explained by blockage of all subtypes of opioid receptors, which have a different influence on ethanol intake [11]. Summarising, alcohol dependence is a very complex disorder and its pharmacotherapy should be personalised to avoid severe consequences as it was shown by using the non-selective opioid antagonist. 


\section{Morphine tolerance in HA and LA mice}

Another issue related to dependence studied in HA and LA mice was the phenomenon of tolerance. Both lines were examined for tolerance to morphine-, stress-induced analgesia and cross-tolerance between them. Panocka et al. showed that an approximately 2-week period of everyday swimming can cause tolerance to stress-induced analgesia in mice. By applying more severe procedure of chronic stress (swimming every $2 \mathrm{~h}$ for 2 days), it is possible to produce cross-tolerance to analgesic effect of morphine. They explained this phenomenon by continuous ligand binding to opioid receptors which causes their desensitisation during harsher stress procedure [15]. Repeated injections of morphine also produced tolerance, resulting in decreased analgesia effect of this drug. HA mice are more sensitive to morphine-induced analgesia approximately 4-fold, despite that there were no differences in the degree of tolerance to morphine between HA and LA mice [40]. Further studies, in which a nonclassical model of dependence was used, showed that despite genetic differences between both lines, there were no differences in the degree of morphine dependence [41].

\section{Conclusions}

We concluded that due to very unique characteristics of HA and LA mice such as a different endogenous opioid system activity and differences in blood-brain barrier structure, they can be used in a broad spectrum of medical studies such as alcohol dependence, pain or melanoma studies. Studies on our model showed that the naloxone, an FDA approved the drug, can be very dangerous in the therapy of people with enhanced opioid system activity. Also, our results indicate that pharmacotherapy of alcohol-dependent patients is very complicated due to individual traits in patients. Accordingly, it should be personalised in the most cases.

\section{Acknowledgements}

This work was supported by the National Leading Research Centre (KNOW2015/CB/PR01/40) and Project No. S.I.1.3.

\section{References:}

1. Gianoulakis C. Influence of the endogenous opioid system on high alcohol consumption and genetic predisposition to alcoholism. J. Psychiatry Neurosci. 2001; 26(4): 304-318.

2. Gilpin NW, Koob GF. Neurobiology of alcohol dependence: Focus on motivational mechanisms. Alcohol Res. Heal. 2008; 31(3): 185-195.

3. Nutt DJ. The role of the opioid system in alcohol dependence. J. Psychopharmacol. 2014; 28(1): 8-22. https://doi.org/10.1177/0269881113504017

4. Nestler EJ. Genes and addiction. Nat. Genet. 2000; 26(3): 277-281. https://doi.org/10.1038/81570

5. Kendler KS, Prescott CA, Myers J, Neale MC. The structure of genetic and environmental risk factors for common psychiatric and substance use disorders in men and women. Arch. Gen. Psychiatry. 2003; 60(9): 929-937. https://doi.org/10.1001/archpsyc.60.9.929

6. Verhlust B, Neale MC, Kendler KS. The heritability of alcohol use disorders: a meta-analysis of twin and adoption studies. Psychol. Med. 2015; 45: 1061-1072. https://doi.org/10.1017/S0033291714002165

7. Moos RH, Moos BS. Rates and predictors of relapse after natural and treated remission from alcohol use disorders 2006; 101(2): 212-222. https://doi.org/10.1111/j.1360-0443.2006.01310.x

8. Charbogne P, Kieffer BL, Befort K. 15 years of genetic approaches in vivo for addiction research: Opioid receptor and peptide gene knockout in mouse models of drug abuse. Neuropharmacology. 2014; 76(PART B): 204-217. https://doi.org/10.1016/j.neuropharm.2013.08.028

9. Sacharczuk M, Juszczak G, Sliwa AT, Tymosiak-Zielinska A, Lisowski P, Jaszczak K, et al. Differences in ethanol drinking between mice selected for high and low swim stress-induced analgesia 2008; 42: 487-492. https://doi.org/10.1016/j.alcohol.2008.05.006

10. Sacharczuk M, Leśniak A, Lipkowski AW, Korostynski M, Przewlocki R, Sadowski B. Association between the A107V substitution in the delta-opioid receptors and ethanol drinking in mice selected for high and low analgesia. Addict. Biol. 2013; 1-9. https://doi.org/10.1111/adb.12030

11. Poznanski P, Lesniak A, Korostynski M, Szklarczyk K, Lazarczyk M, Religa P, et al. Delta-opioid receptor antagonism leads to excessive ethanol consumption in mice with enhanced activity of the endogenous opioid system. Neuropharmacology. 2017; 118: 90-101. https://doi.org/10.1016/j.neuropharm.2017.03.016 
12. Sacharczuk M, Juszczak G, Swiergiel AH, Jaszczak K, Lipkowski AW, Sadowski B. Alcohol reverses depressive and pronociceptive effects of chronic stress in mice with enhanced activity of the opioid system. Acta Neurobiol. Exp. (Wars). 2009; 69: 459-468.

13. Sacharczuk M, Ragan AR, Szymanska H, Lesniak A, Sadowski B, Lipkowski AW. Distinct susceptibility to inoculated melanoma and sensitivity to cancer pain in mouse lines with high and low sensitivity to stress. J Env. Pathol Toxicol Oncol. 2012; 31(2): 167-177. https://doi.org/10.1615/JEnvironPatholToxicolOncol.v31.i2.80

14. Ragan AR, Leśniak A, Bochynska-Czyz M, Kosson A, Szymanska H, Pysniak K, et al. Chronic mild stress facilitates melanoma tumor growth in mouse lines selected for high and low stress-induced analgesia 2013; 16(5): 571-580. https://doi.org/10.3109/10253890.2013.807244

15. Panocka I, Marek P, Sadowski B. Tolerance and cross-tolerance with morphine in mice selectively bred for high and low stress-induced analgesia. Pharmacol. Biochem. Behav. 1991; 40(2): 283-286. https://doi.org/10.1016/0091-3057(91)90553-E

16. Panocka I, Marek P, Sadowski B. Inheritance of stress-induced analgesia in mice: Selective breeding study. Brain Res. 1986; 397: 152-155. https://doi.org/10.1016/0006-8993(86)91380-6

17. Gajkowska B, Kosson A, Sacharczuk M, Kosson P, Lipkowski AW. Blood-brain barrier permeability differentiates Sadowski mouse lines of high and low stress-induced analgesia. Electron microscopy analysis. Folia Neuropathol. 2011; 49(4): 311-318.

18. Kosson A, Krizbai I, Leśniak A, Beręsewicz M, Sacharczuk M, Kosson P, et al. Role of the blood-brain barrier in differental response to opioid peptides and morphine in mouse divergently bred for high and low swim stress-induced analgesia. Acta Neurobiol. Exp. (Wars). 2014; 74: 26-32.

19. Panocka I, Marek P, Sadowski B. Differentiation of neurochemical basis of stress-induced analgesia in mice by selective breeding. Brain Res. 1986; 397: 156-160. https://doi.org/10.1016/0006-8993(86)91380-6

20. Gianoulakis C. Endogenous opioids and addiction to alcohol and other drugs of abuse. Curr. Top. Med. Chem. 2004; 4(1): 39-50. https://doi.org/10.2174/1568026043451573

21. Devine DP, Wise R. Self-administration of morphine, DAMGO, and DPDPE into the ventral tegmental area of rats. J. Neurosci. 1994; 14(4): 1978-1984. https://doi.org/10.1523/JNEUROSCI.14-04-01978.1994

22. Walker BM, Koob GF. Pharmacological evidence for a motivational role of kappa-opioid systems in ethanol dependence 2008; 33: 643-652. https://doi.org/10.1038/sj.npp.1301438

23. Roberts AJ, Gold LH, Polis I, McDonald JS, Filliol D, Kieffer BL, et al. Increased ethanol self-administration in delta-opioid receptor knockout mice. Alcohol. Clin. Exp. Res. 2001; 25(9): 1249-1256. https://doi.org/10.1111/j.1530-0277.2001.tb02344.x

24. Gaveriaux-Ruff C, Kieffer BL. Opioid receptors genes inactivated in mice: The highlights. Neuropeptides. 2002; 36(2-3): 62-71.

25. van Rijn RM, Brissett DI, Whistler JL. Dual efficacy of delta opioid receptor-selective ligands for ethanol drinking and anxiety. J. Pharmacol. Exp. Ther. 2010; 335(1): 133-9. https://doi.org/10.1124/jpet.110.170969

26. Froehlich JC, Zweifel M, Harts J, Lumeng L, Li TK. Importance of delta opioid receptors in maintaining high alcohol drinking. Psychopharmacology (Berl). 1991; 103: 467-472. https://doi.org/10.1007/BF02244246

27. Lê AD, Poulos CX, Quan B, Chow S. The effects of selective blockade of delta and mu opiate receptors on ethanol consumption by C57BL/6 mice in a restricted access paradigm. Brain Res. 1993; 630(1-2): 330-332. https://doi.org/10.1016/0006-8993(93)90672-A

28. June HL, McCane SR, Zink RW, Portoghese PS, Li TK, Froehlich JC. The $\delta 2$-opioid receptor antagonist naltriben reduces motivated responding for ethanol. Psychopharmacology (Berl). 1999; 147(1): 81-89. https://doi.org/10.1007/s002130051145

29. Hyytiä P. Involvement of $\mu$-opioid receptors in alcohol drinking by alcohol-preferring AA rats. Pharmacol. Biochem. Behav. 1993; 45(3): 697-701. https://doi.org/10.1016/0091-3057(93)90527-Z

30. Van Rijn RM, Whistler JL. The delta1 opioid receptor is a heterodimer that opposes the actions of the delta2 receptor on alcohol intake. Biol. Psychiatry. 2009; 66: 777-784. https://doi.org/10.1016/j.biopsych.2009.05.019

31. Roberts AJ, Mcdonald JS, Heyser CJ, Kieffer BL, Matthes HWD, Koob GF, et al. $\mu$-Opioid Receptor Knockout Mice Do Not Self-Administer Alcohol. 2000; 293(3): 1002-1008.

32. Hall FS, Sora I, Uhl GR. Ethanol consumption and reward are decreased in $\mu$-opiate receptor knockout mice. Psychopharmacology (Berl). 2001; 154(1): 43-49. https://doi.org/10.1007/s002130000622

33. Giuliano C, Goodlett CR, Economidou D, Garcia-Pardo MP, Belin D, Robbins TW, et al. The Novel $\mu$-Opioid Receptor Antagonist GSK1521498 Decreases Both Alcohol Seeking and Drinking: Evidence from a New Preclinical Model of Alcohol Seeking. 2015; 40(13): 2981-2992. https://doi.org/10.1038/npp.2015.152

34. Kovacs K M, Szakall I, O’Brien D, Wang R, Vinod Y K, Saito M, et al. Decreased oral self-administration of alcohol in к-opioid receptor knock-out mice. Alcohol. Clin. Exp. Res. 2005; 29(5): 730-738.

https://doi.org/10.1097/01.ALC.0000164361.62346.D6 
35. BlednovY A, Walker D, Martinez M, Harris RA. Reduced alcohol consumption in mice lacking preprodynorphin 2006; 40(2): 73-86. https://doi.org/10.1016/j.alcohol.2006.12.002

36. Walker BM, Zorrilla EP, Koob GF. Systemic kappa-opioid receptor antagonism by nor-binaltorphimine reduces dependence-induced excessive alcohol self-administration in rats. Addict. Biol. 2010; 16: 116-119. https://doi.org/10.1111/j.1369-1600.2010.00226.x

37. Schank JR, Goldstein AL, Rowe KE, King CE, Marusich JA, Wiley JL, et al. The kappa opioid receptor antagonist JDTic attenuates alcohol seeking and withdrawal anxiety. Addict. Biol. 2012; 17: 634-647. https://doi.org/10.1111/j.1369-1600.2012.00455.x

38. Morales M, Anderson RI, Spear LP, Varlinskaya EI. Effects of the kappa opioid receptor antagonist, norbinaltorphimine, on ethanol intake: Impact of age and sex. Dev. Psychobiol. 2013; 700-712. https://doi.org/10.1002/dev.21137

39. Sacharczuk M, Sadowski B, Jaszczak K, Lipkowski AW, Swiergiel AH. Opposite effects of alcohol in regulating stress-induced chanes in body weight between the two mouse lines with enhanced or low opioid system activity. Physiol. Behav. 2010; 99: 627-631. https://doi.org/10.1016/j.physbeh.2010.01.023

40. Lutfy K, Sadowski B, Kwon IS, Weber E. Morphine analgesia and tolerance in mice selectively bred for divergent swim stress-induced analgesia. Eur. J. Pharmacol. (Molecular Pharmacol. Sect.). 1994; 265: 171-174.

41. Kest B, McLemore GL, Sadowski B, Mogil JS, Belknap JK, Inturrisi CE. Acute morphine dependence in mice selectively-bred for high and low analgesia. Neurosci. Lett. 1998; 256: 120-122.

https://doi.org/10.1016/S0304-3940(98)00772-1 